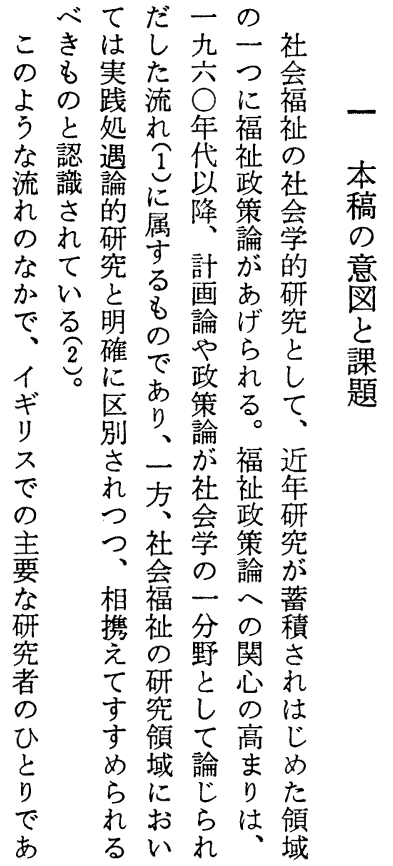

政に織こ定略究る 中府なはの: 它 $\mathrm{R}$ の立が央加施も欠 行法、のののつ怘、 政府政行政組機状卜 府の策政策織能態 - 研 の府の分のの 立究発・決析研な は 法は案立定究か福 府重: 法・供 $\widehat{3}$ で祉 の要審府実給ここ政 研課議か施のにれ策 究題. らの機たら論 にの成地組態おの諭 おひ立方織分。二 課 てとにの分析こ! 題 、でい業にと課をを そある焦関お方題充二 にる焦関いえ直洼連 関組施、真需す量 す織設そこ要る社 るとまのと突た会 社なで対が析め的 会るを象で吕二 事中含とき政組 象央むなよ策織ド

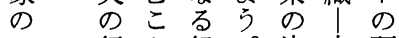

本先事例つ公ま列 稿がをいとず即稿 はととで、生生政 政っり嘋生て 社戦げ活保 保討祉 会略考保護護す政 学が察護法政る策 的注守の考策こ研 あ目る政主をと究 るさ。策 プシをに いれそ決口ス課お はるの定グテ題け 官。際尞公公省組

制組テとデる織 . 織么すル。理 行連のると論 政関組制し導 社関織度て 入 会係連シ と の

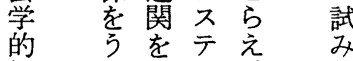
視 みあ山文 角 だき加政方

ら基吕構決件

の盤に成定生石 社とすさシ 活 会しるれス 保 てたるテ護 のめこム 政 資にと策 源、衣政索 稀活め策 奏市

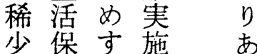

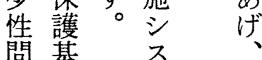
題準 そ そ との ム の 価な 政 値か 異策 規生義決 範活立告

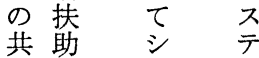
有基染公 対㔼六 に 立老のけ 問 龃 三 題 加 戸 組

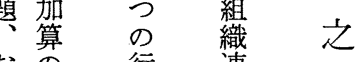
おの 行連 びう 為 音 厚の ス 事
生
活
保
護
の
政
策
決
定
今
ス
テ
に
に
お
け
る
組
織
連
関

藤

村

正 
り織決 あ体群分互学祉とて。りの態省に政の般

$\widehat{6}$ の定もろをの析作に政の諸恕強相ので福よ諸策設的

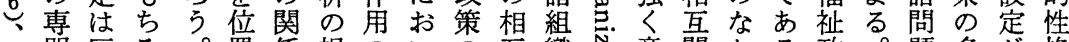

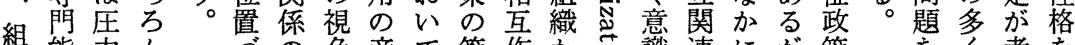

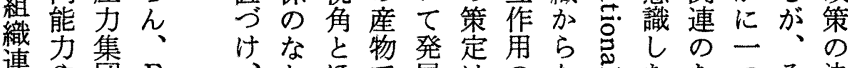

摰 団 $\mathrm{F}$

利なかほで展はのな的なたて決

視犁な゙

角関の।

学要ク

そでぼあし行シるす組だだの定

の政一るて政スと先な織な組・

行策致ときのテみ㐫研か孤織奏

為架等いた問么て心究に立は施

ちが求が

方政学指

を決るう政題の、がの存しいに

策反摘

把定。仮治で形環市了在てわお

?尔映す

中進する

心展る る

な有の に

る有で行

行なる政

政 要と官

握さそ定過あ成境あプし存ばい

守れ炛程るやた る

るてゆ採研究変る諸。立いて験

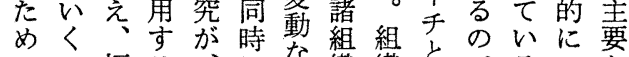

を考を

組 がえ認

織 組 $ら$ 識

現織れ高

象をるる

にこ福る、にな織織しでるつな

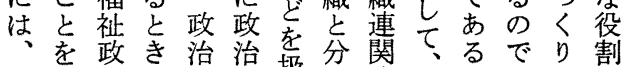

亡通。方

しじ組 法

て 織 の

と 決 理一

ら定論つ

えさにと

てれ依し

い、趑て

く寒す

こ施る組

とさ理 織

がれ 由 理

組考策、、はの势析分組。はだを

組 恩同 僚

織で時 制

にあにに

焦る、清

点場官计

苦僚る

あ多制 政

織慮にそ諸問う対析組こなさ担

連苾関の組題も象は織のくれう

有るは、論

関れ与仮織ででた、連よ、奍な行

効以、に

視ばす定のもでる環分う多社政るそ社し

角、るは錯市特境析な数会官とれ会た

が各行組綜るる定を析認の的庁

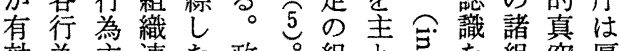

てあ組策

効為主連た政。組と离を組空厚

いらに分

うをお析

判內け枠

断ぐる組

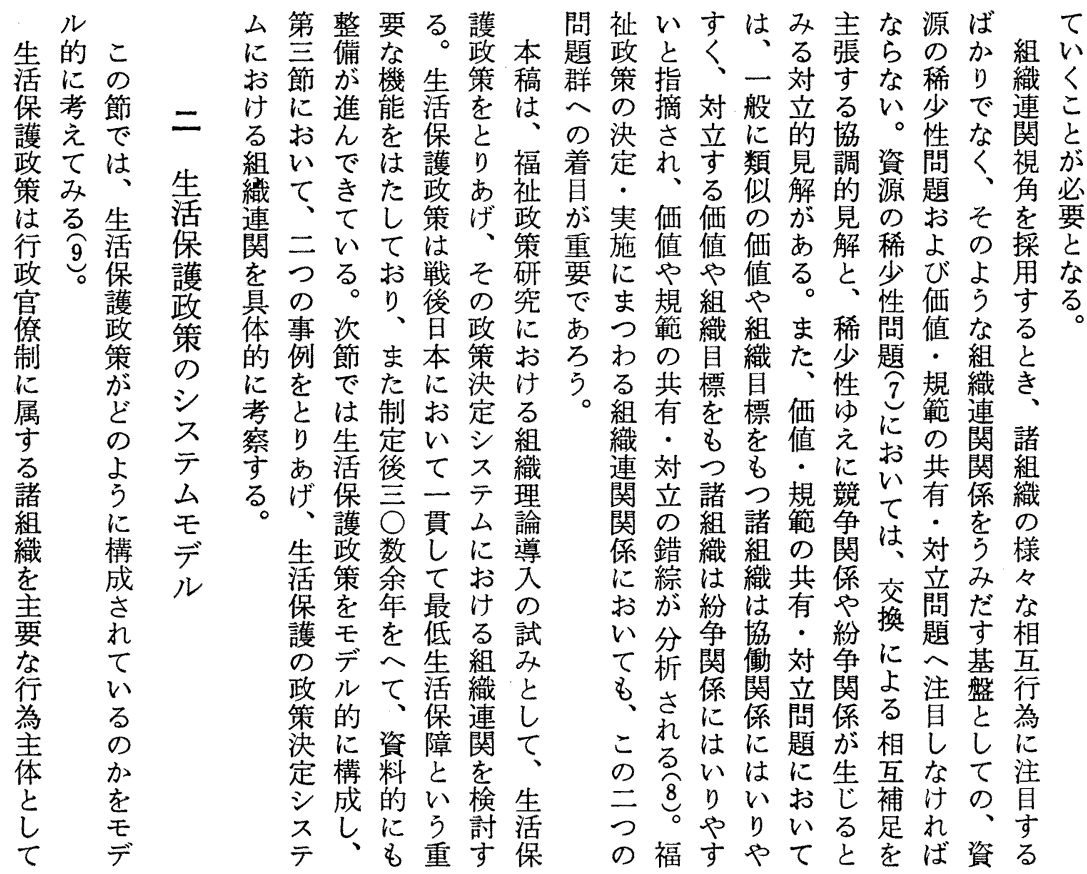


におを権定資かに具題よつる いめ力シ源がた体解ぼにの生

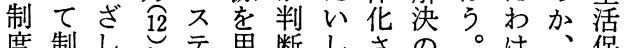

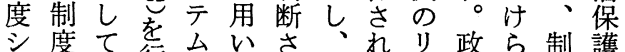

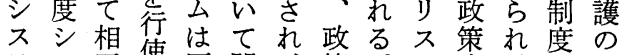
テ不互使厚問、策。決、行 公作し生題適実ま之定前 のム用つ省解切施たの莪テシ

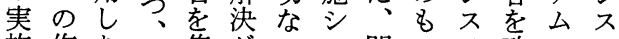
施作あ自焦が解不問のテ政にテ を成 引自点は決テ題がム策従么 童。行兄組吕方公解作に決心は 決為要織ら法に決成お定つ标 け定シ案とれ茂おにさいシさ制 るの不求しる手い必れて 資たテ制た。持て要、はテ為芝

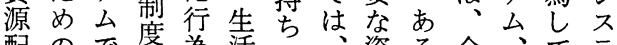
配ので菜為活の、資る全、てテ 分合あ逶保り問源い资後いム す意る。祭護不題配は新者くを な形。テで政命が分りたを場作 わ成こ允あ策卜どがスな政で成 ちがのにりにから決卜発策あ! 生な行反、お選定定が想実る決 活さ為映各い選型さ拡に施の定 保れ学さ行て导にれ大基永か寺 護るスせ為、さ属る・基艺にる 予とテる焦政れ势。修いテょ場

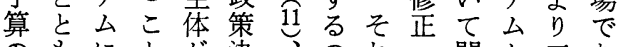
のもにとが決、のれ!問と三あ
るはる制はる配あいお ひが御実このるるこ と、機定と最行。な まそ能法を染しわ ずのをつ意純シたれ シ有々図粋不がる 生不贾しなテつが 活テるさ 型么て、 保ムシひいでが、そ 護をンとるあ存それ の制ボい。る在こ以 制度ルう行がすに外 度シ情法政、るはの シ ス報規官そ。行諸 ステの範僚れ一為組 テムシで制は方主織 ムとスあに明、体も とよテるお確官群 組 行ぶム危いな僚に織 為こが こて 規制よ連 シと法行々則はる関 スに規行そに技行関 テす範為のよ術為係 厶るをシよう的連壳 と。中, し生心テな行みのし て活にム規為てシて 構 保 構に則を合 ス関 成護成対の制法テ与 さ政さす中御的么し れ策れる心す支でて

行る会焦過体をの定立に内点グし則わト貝シ䒠確 連程保組をならべのき改い決織么そ通らの方達テを厉を゙

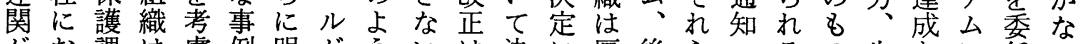
がお課は慮例明がういは決に厚後ら方るの生をに任さ すいで厚し分細あな与立定他生者を通。と活実拘され でてあ生な析华る着件法さの省をま達そ、保際束れる。

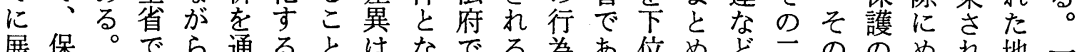
開護しあ記しこを逆るのの主るプてとつリ制ざつ方方 し課たるせてとしに。審に体がロプのはス度すつ自 てをががばはがめ、議たか、グロ区実トシシ、治政 い焦っ、次た必し政をいら下ラグ別際のスス被体策 る点てよのさ要て策要しの位ムラでに拡テテ保を実

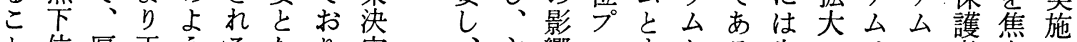
と位厚正うるなり定、主響品とる生ははで者点 に組生確にもる、㷞プがグる名。活修、市組 な織省になの。前ス生品あラ。ゔ保正前る最織テ るとがいるだそ述テ 省グつム政け1護・述。低と厶 。しプえ・がののム注たで策艿チ法具の 生しは こた口唯生、明政の公を決、とそ体よ活た主

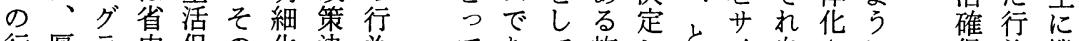
行厚ラ内保の华決為てあて施方とイ自さに保為機 為生么下護概自定連はるも行不にモ身れ、連関 連省を位政略体卞関自生、細テにンとた問自関委 関内立組策をは学活厚則么前の过題立で任 を部案織を政次テも宁保生なに者用その解助あ事 省に: 蓮策節么い文護省どおを語のの決長り務

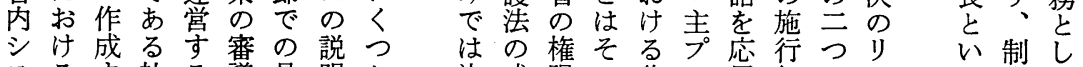
スるす社る議具明か 決成限の焦口角細にスう度て 
譜プなデる器害えっ体力る。と連なテなにる。拿こ局テ

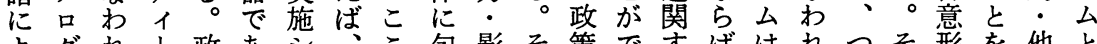

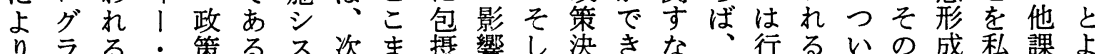

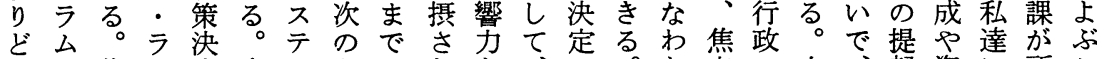

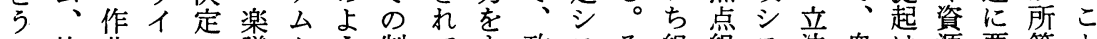
い施曲ンシ譜とう制ても政スそ組組ス法衆は源要管と う行はをスがはな度いつ策テれ織織テシ議ま獲求すに 楽細主うテ同演もシる以決么ら連内公不院す得するし 器則にくムじ奏のスこ上定はの関のとテ他がる社よ が・主るはででにテと方そシと内しム参省必原う 必通 プ作楽\&市な厶はそスのスし的てと議庁要厚保。 要知口曲譜楽るろといれテ重テて行まの院やな生障省

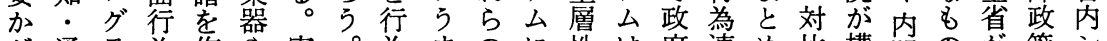
が通 ラ為作や実。為まのに性は府連め比構閣のが策シ き達么と成演施制シでシ関を重シ関らで成には妾と页

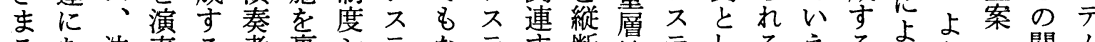

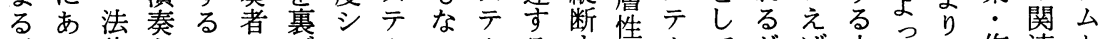
がた律をシにら゙スムいムるすを索劣がば立て上作連と

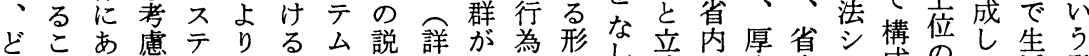

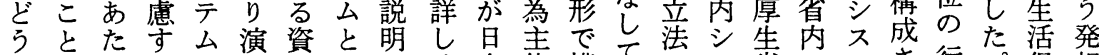
いにりるだ奏源はをく本体構で省省シテさ行プ保想

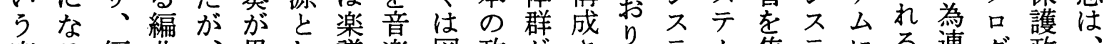
楽る編豊、異し譜楽図政がさ䒘 器。曲行そなてでに 2 治され帒㕕を点么た政関ラ策厚 をそは為こるのあた参シまる亦組とい府に市生 使し主とでこ予りと照不ざこ生あ外織政しシ提のと省 えてにがはと算、え并市まと活げ的と府てス起うら内 る、下おメがは政て ムなに保る行すシおテさちえの か楽位こ口あ楽策い全権な護こ為るスこムれ、る他

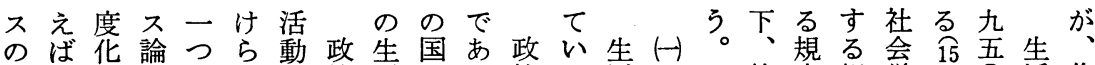
拡、第定規学策活民活作 大ラ拡有観る具貝保に、理。保政咅。定的第年保曲 はイ大効点。体標障対日念護策節こ的に護行 政フの五生的は法理でれけみ本は全の為 策・晋活に、自、国コの念のら政て章面制や のチつる入保方抽立そ憲こ第定事の策大章的度編 対 $の$ の護向象のの法の政例内実き則にシ曲 象ン発ダ考法方的助困第法章策分容施上則改不行

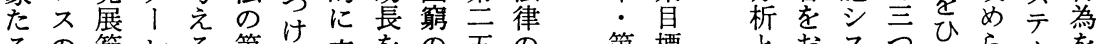

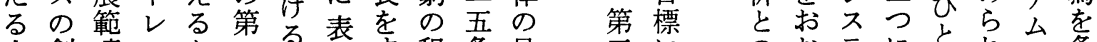

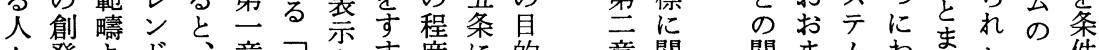

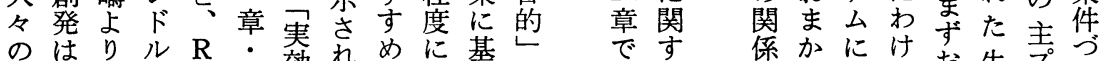

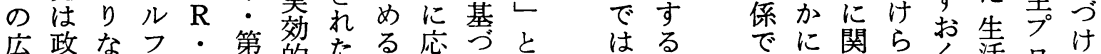

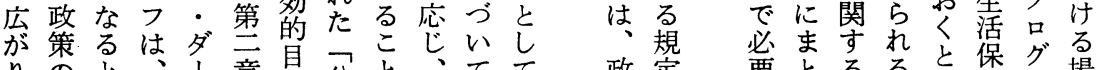

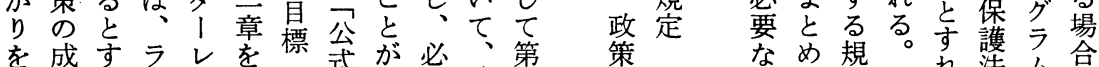

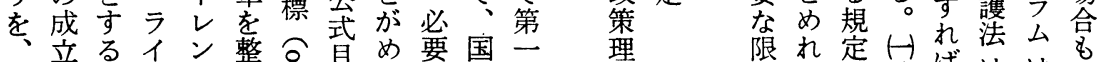

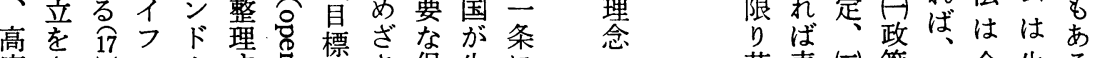

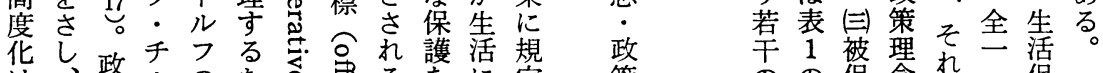

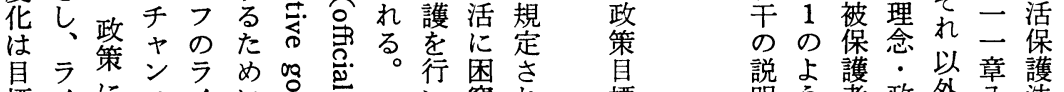
標イにスイに旁窮れ標明う著政外分法

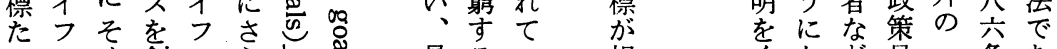
る・く創・ ら范第るい規など目一条あ

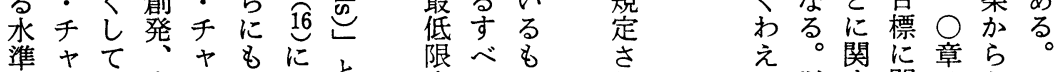

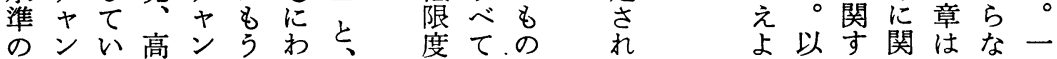


表 1 生活保殿の制度システム・主プログラム—生活保護法の桙成

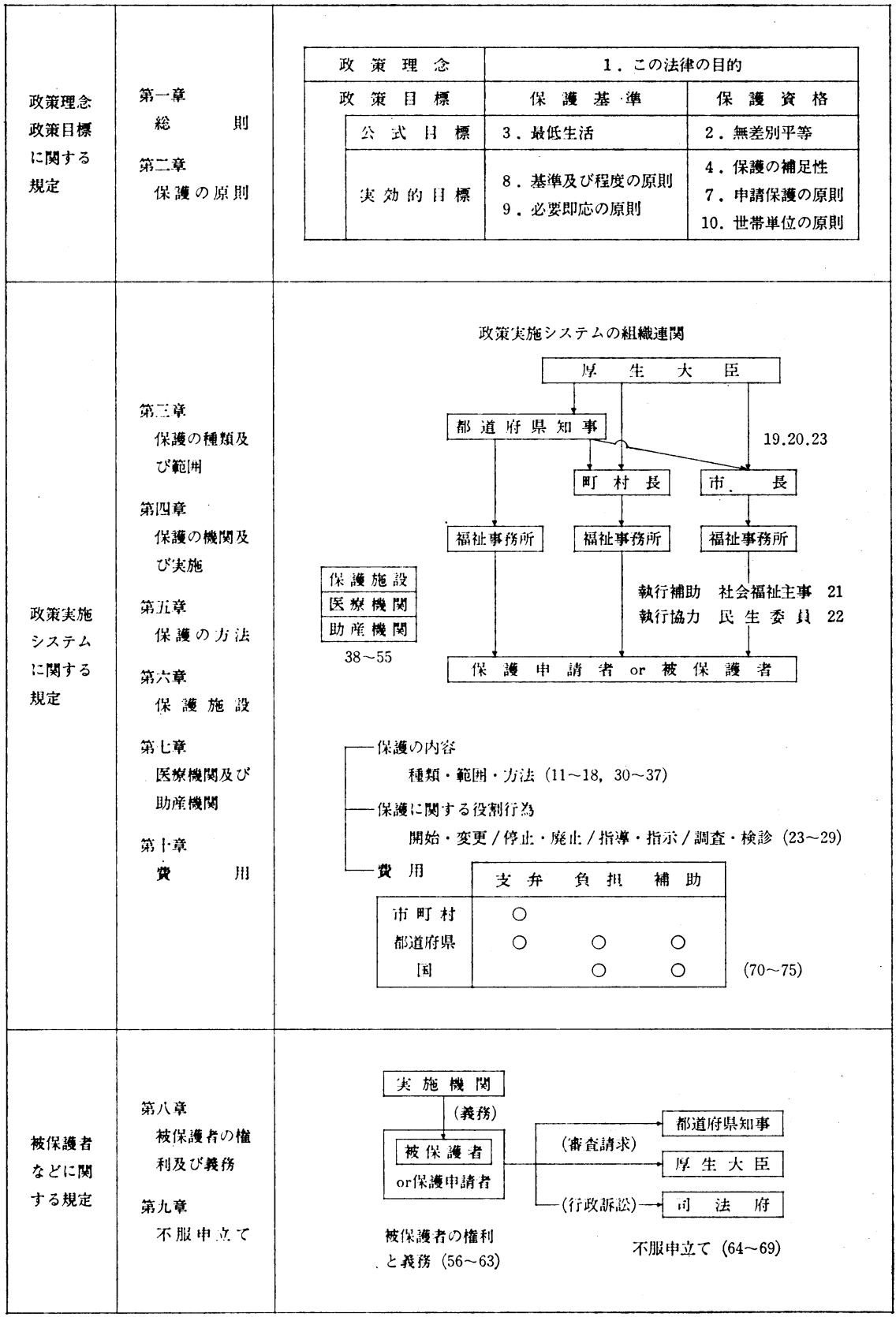


異議申立てシスデム图1. 生活保萑政策のシステムモデル

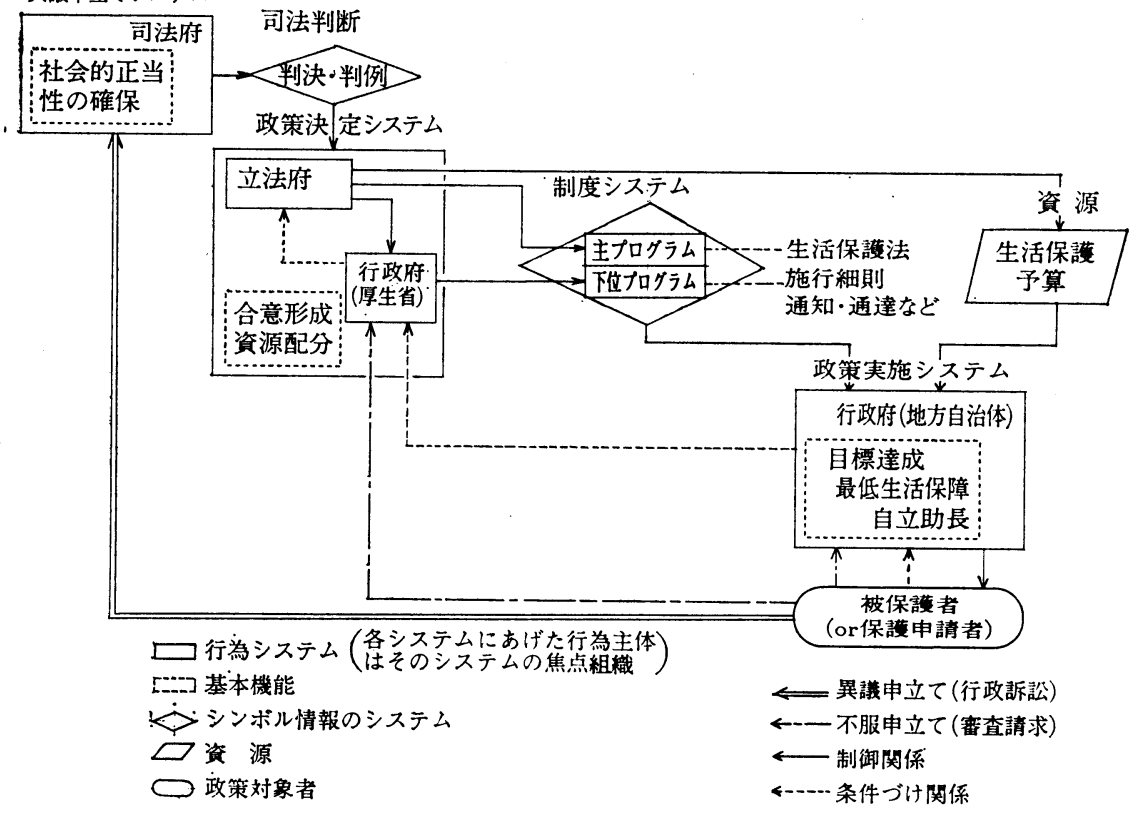

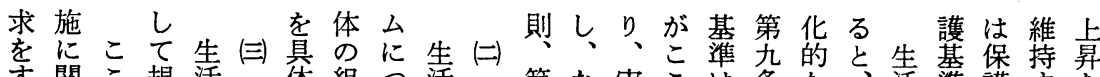

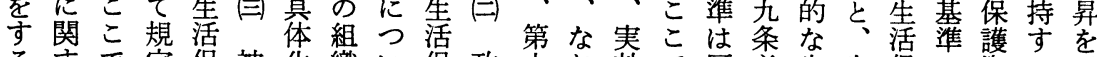
るすで定保被化織い保政十お効で厚必生生保の凟る示 こるのさ護保し連て護策条生的な生要活活護問格うす

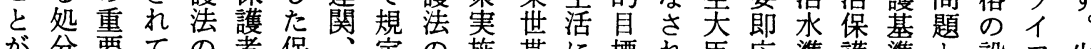
分分要ての者保定の施带に標れ臣応準護隻と設フ生 でにない第な護実さ第シ単困はてがのし基とし定・活 き不項る公ど内施れ音不位窮第い定原で準保てのチ保 る服自。章に容にて章テ閏す四るめ則あの護考問 †護

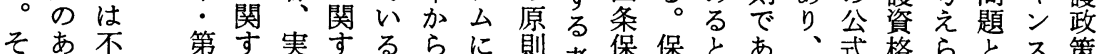
れる服杂る施る。第関で者護護規る実目にれしのに

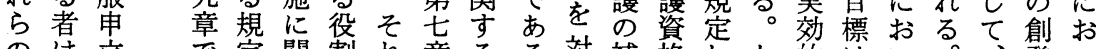
のは立で定関割れ章るる対補格しな的はいる。発い 雷、宁す行らお規。象足のてお目第ててラとて 香都で、る為のよ定と性公あ摽第て、イみは

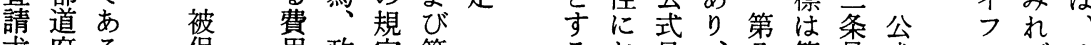
求府る保角政定第方お目、分第最式・代そ の県。護に策は十 裁知保著わ目章 決事護お標実で 兹厚要占占の施は 程厚要 後 大 決 臣定 なにお お審よ 不查び 服請 実 びれうに 保るち関 政 護。のわ策 実る実 効 諸 施 的行 $シ$ 目為 標主 テ こけ標政条八低目チ、の とるは策第条生標中 資第決一基活 . ンイ立 第産定項隻に実不フを 七。条シに及お効的・最 条能無不おびけ的高于低 申力差テい程る目度 請な別ムて度つ標化ン度 保ど平へ、の健をはスの 護を等の保原康み䅉の生 の活で言護則でて 活拡活 原用あ及の文み保大を 
康 活

でと生 (1)

花萿

的政護活三

な策法保

生目に護

活標お基

水のい準

準うての

を交決

維の政定

持公策

す式理

る 具念

こ標と

があて

でる国

き第民

る に

\&条保

のに障

と明守

い記る

うさ最

規れ低

定て 限

にい度

おるの

万健生
み準れのにはよ粱たテ概以場㕕訟府の うなのううど生生プ構こと芒な略以関司る 。か論なの活活口成れいあがる司す法者 の点位よ保保グすに放る、。法る府は 生に置亏護護うれ、兰。生府行の訴 政活関にな基基么ば政うこ萿をを為順訟 策扶しあも準準か図策のの保判シにを 決助、りののののら 1 決行な護断 ス問提 定基 ラ、か決決みの定為かの主テ題起 準イど、定定れよシシで制体ムをで とフのそをとばうススは度とを開き 老・よしめ心、にテテ、棌示る 龄 チうてぐう政な厶ム政ス議し 加ヤなるるこ策るをを策テ、不 算ン行そ政々決。含制実么 行立い服 のス為の策と定め御施の政てくの 二の戦組決だシて御主府シこあ つ高略織定けス堹すスプのスとる の度を連シがテ活るテ六行テに者

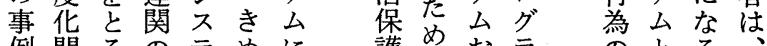
例問るのテめに を題のな厶らつ とでかかのれい りあ。で組てて ある次、織いは げ生節厚連る嬮 考活で生関縲保 し護、は実れ臣 て基こど際でに
護めお ラ

政のよ允

策嫢びた

毛が議生 デな申活 ルさ立保 的机宁護 簡いスの
にてシ法
のとる

社よ。地 的うの自 当こち、体 をシ行中 争 不政 央 亏訴 政 正。弓治

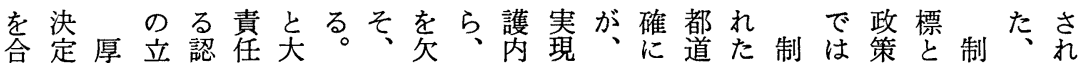
理に生場可者蔵ま立くこ容に結規府行定決し度抽る 的政大を。大た法恐れはい局定県為当厚定て必象。 か治臣徹都明臣、府れを経た、知主時生シ生ス性こ つ的に底道確の保でが法済ら技る事体の大活テのの 科色よさ府に協護はあ律状な術こなは状臣テ保么高規 学彩るせ県す議基なるで況か的とど、況にム護をい定 的の決る知る決準く規につ準にで厚かよに基実もは な混定と事と定は厚息定た備関あ生らる準施の日

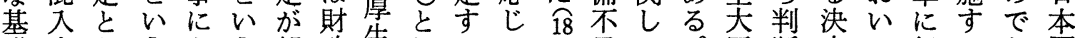
礎すなうよう望政生しるて 資るる理る理まに臣てこ年こ、ここ教

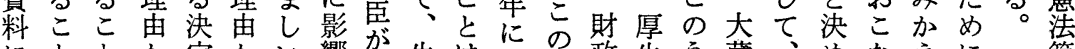
にととか定かい響㭈生は数点政生う蔵、めなえに第

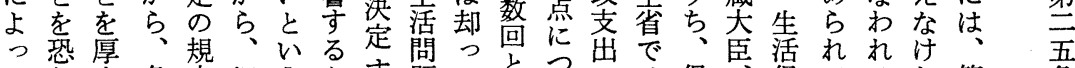
て扎生各定旧 うとす題てとつのは保堡てるれ第条 算て省々に生意こるの固ない激豆護立護いこば恶第

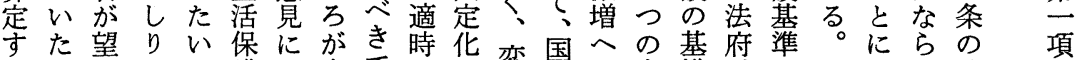

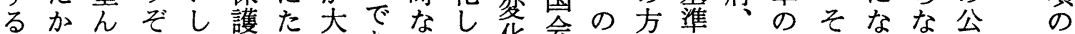
こらだけて法いきあ解て化会不法を特決れるい式表 とでのらはでしいる決保す法安方立別定はが。目琴

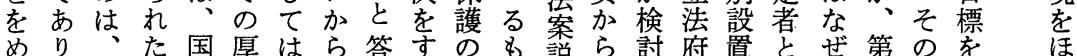
ざ、保 20 の生、并る円の腹、さがのしか分組、流 し保護。直茞終厚さた滑ででそれ法審で条み萶繰

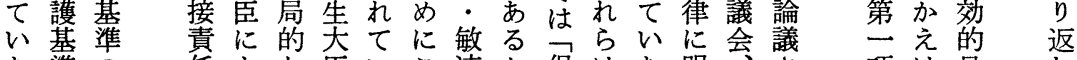
た準の任よな臣いこ速か保はた明会さ項は目し 
この施のきち人式 $\bigcirc$ 導みし基は

に適状費な理医は変九改さげ時蕉生活

がな定もラか

る华にの而療急更吾定れる期主活保生

、策い大結助しれ年で一1つ設護基扶

適のてに核人たるに用九ケい定に準助

正実の危患員がま新い六ッて守よに基

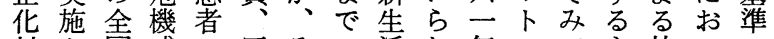

対と国感の医その活れ年・ても扶い

策保調を薯療れ事保た四バいの助て

と護查心延扶も情護

し基をだ化助三を法

て準おいと費年のが

改こた医はほべ成

医定な大療確どて立

療のい蔵保実でみし

扶見、省険におよて

助送保雀制増ちうか

運り護会度加つ。ら

嫦を濫計のしい新

要愿救検末てた法算

領生の查整い。施定

の省存院備たし行方

制に在はで。かと式

定要索生あそし、同が

と請指活るの、時工

外し摘保。増保にン

国た護こ加護被ゲ

保望保護実ら

月不くでの

第 ッエるち定

一トンが、方

七方午、日式

次式ル以常と

定恣式方生活

加意はエの従

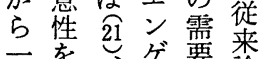

九克、克要論

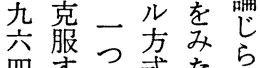

四する式たら

四むつ噵生て

月の品を活き

のと貝中扶た

第しを心助を

展吕、台

開にスこでで

すおテのああ

るかムこるる

これにと生

とておは活し

にいい厚保か

なるて生護し

る以上大法

上星監権護

そ省専限基

のが決を準

決諸権安の

定行. 決

を為自決定

め主由定は

ぐ体裁者厚

つの量の生

七重権範天

層を囲臣

さ的意がに

まな味確よ

ざ組し定る

ま織なさ

な連いれと

行関。た主

為の政と

関だ決てグ

こ最当かしつみ場のラム阻限分の不ン厚介なて護

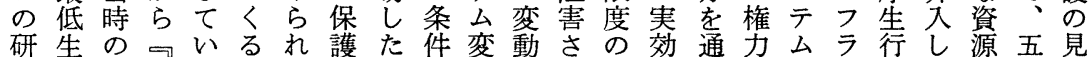
究活保最たこる課のと更のれ生的じバ内ン政てを直 はの護低。と恣でがしの動る活目てラでシのき配年し 政費基生そに意は、学思。標権ンのス進た分をが 策角準活の関性、厚不要が政維と限ス变コ展。寻除お 実はは費研心を新生可性準策持しをに動条にこるきこ 施保動に究がと生省欠壳備寒すて発変の約たの統、な シ護物関成そり活内で組さ施るの揮化影にい時轄改わ 不基的す果之の保のあ織れ方と生し、響よし期官定れ テ準生るのがぞ護保る関たスい活、生がりて徽そ胎そが庁筧保

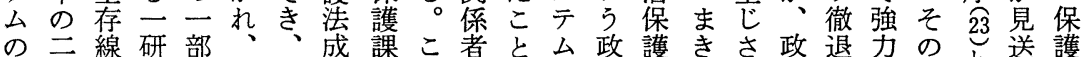
目倍を究は藤議立とのににの策基かせ策しなよとら基 標程確综本論以朝時問な基実準え、決た権うしれ準 達度保と一武の来是期題る本施がしそ要据をの定か方なてたなは の必るて五他地了訟そ示、件不え図変 不要に発四のが।運のすそのテ置つ花テあ揮を限蔵五 充とす表年研なケ動よるの不么かたのムる撙大を省四 足すぎさ厚究いッ体う行動充のれもなにとて蔵駆は年 をるすれ生者ほトでな為秵足目るのかお考き省使政か 科も、た省にどバあ開主をと標ことでけえたがし府沜 学の健。大そ理 スる示体認心達とい大る方 的で康そ臣の論ヶ。主の知 う成に藏組れ $\mathrm{H}$ き算吾

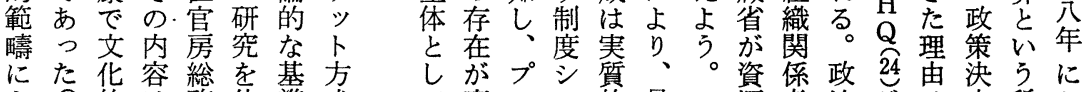
よ 25 的は務依準式変口不的最源者治がは定稀か つ。な、課頼をに登動グテに低配間シササ、に少け 
省的手しでちし的意さ岡助た療ら開力題算り示て 役段た対政て正形朝れ山の措中一示ほ感を起威確 批割をが処府い当成日た県な直の九しぼと開のえ効認 判のと、しシっ性加氏。知か変朝六た同焦示ゆる果す 主差つそ、スたをらを朝事の更旦七の様躁しとたをる

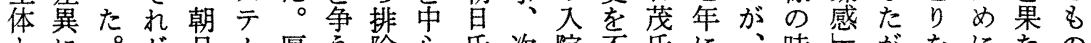

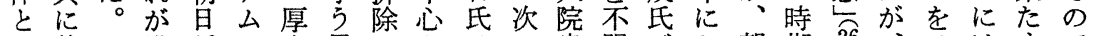
し基こ排訴へ生異さとはに患服がか朝期 26 、ひはすで てうれ除訟影省議れし厚厚者と兄け是にが数き、もあ のくらさ運響は电たた生生昌しかて訴、た年だ関のる 運ものれ動孝政立が朝呑夲用てら争訟政だにす係でが 動の違た体お策てゆ日臣臣品おのわ運策よわ政子も 体でい後はよ決シえ訴をに費こ送れ動実つた治算あ同 とあは、いぼ定スに訟相不のし金た体施てる的のつ時 いる政異つすシテ、運手服不たに裁 27 シい保転大たに う。策議た政不新動ど电充異た判でスた護換幅。政 差そ決申ん治テ命た体り立分議いででテ基がなし策

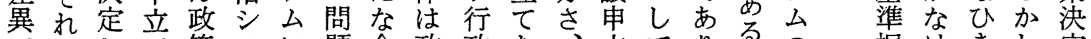
ではシて策スに題合政政を、立てりる。の 据けきし定 あ、页決テお意策訴お補て津、朝標置れ゙げ保文

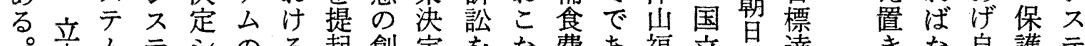
案么テシのる起創定をな費あ福立訴達きな自護テ 主にムス変状寸出シおうのる祉岡訴成年ら体基么 主おへ本容涗るをスこた必。事山訟のの放へ とけ閏么老の主もテしが要朝務療は不保い必の問 とる題へま好体と公た、性日所養一充護。要算題

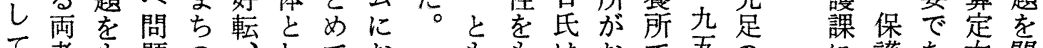

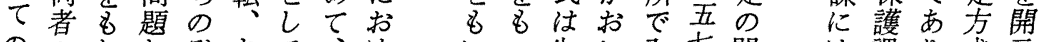
ののちをぞすて、けにっ生こ入艺問は課り式示

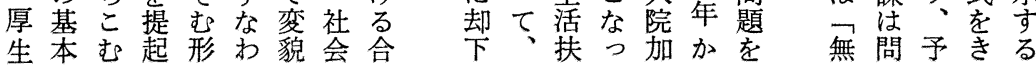

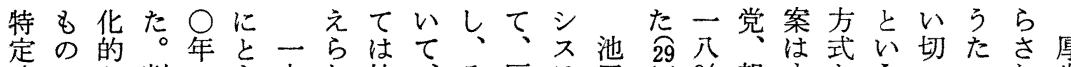

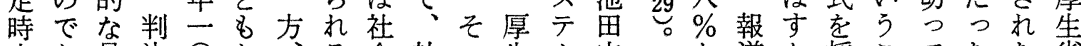

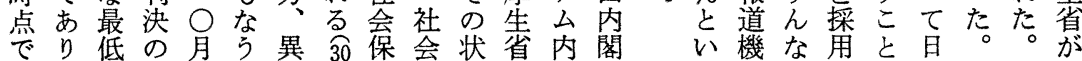

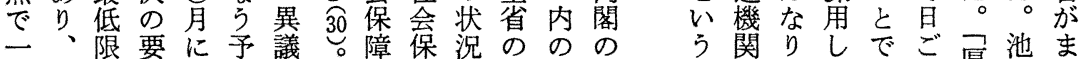

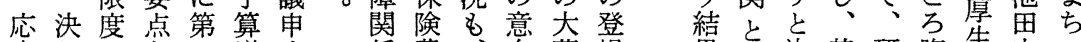
客しの艺一増立係費、向蔵場 観て生社審がて予に所が省に 的之活会果政 シ 算よ得通によ にの水学京策ス全り倍り影っ 決逆準的地決テ体多增や響て 定でしに方定么 のく計すし \& さはと裁シに伸の画い、た れないと判スお び予の状生ら るいうめ所テけの算柱況活さ ここ公るのムる ながのを保れ とと式と判に朝かつ一う護た 保貝標次お昆訴 護たはのおて訟 基々奉うり、番は 準の效に的に厚さ議さ 決準目な生れン 定は標る。大で゙ 権特をつ臣いル 限定規健はた方 はの定康敗—式 第国すで訴九導 でぎつくの政 整こでり政治 備まあだ策シ 岢れるた策 ス 能生会た定公 に活保とシの な保障いス変 つ護のえテ容 た費充るムは、 とに実。に政

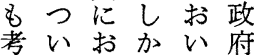
果笨決基研腹頶内の にっま準究の省閣ぞ なたつ改者底とはん り、行た定たに国だ 、行わ率ちして虚政 工為け三去加所治 ン佉で六らい”得 シ ゲ体な\%利こ社倍ス ルとくと用ん会堌テ

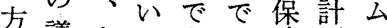
式議大うきお障画の へ論蔵予るつ株を変 とが省算とた”か容 プ紛案認計のかは プ紏経をめ画上げ、池 グす済提ら竞ら、田 ラ゙る企出れ出た社内 ラな画して出こ会閣 ムか庁たいしの保に がで、。たて機障よ 変、自こエや会のつ 更改由のンれに拡て さ定民予ゲ允充も れ率主算ル28思をた 
蔵積独半がでてう財 題た施あ門がびし定司次 省極で以存は重資政生にが生主著技ら省確傍かシ法的 は的権降在な要源的活つ、活張し術たは保論し、不府に 予に限はしくな配に保いこ扶しく的め生さで、テも厚 算介を自た、役分裏護ての助続不判、活れはつム行生 編入駆由。大割を基次事算け合断実扶た実うに為大 成す使民そ蔵をおけ準の例定、理と効助。質いお主臣 権るし主の省にこらのこか基司で政的算結的てけ体に のまた党組にななれ決とら準法な治目定局に争るとあ 主でとで織働ううな定が、に府い行標方愿わ厚しる 体のいあはら。統けは小資エに限政の式朝生れ生てが で間えつ一きし轄れ厚括源ンより的水を早た省政 はにるた九かか官ば生でのゲる厚判準吕訴臣東の策法 あおが。五けし庁政大き稀ル法生断をン訟が京保決律 つい、五○、、た策臣よ少方的省のあ年が勝高護定へ てて自○年そ大るをにう性式支の双げル争訴等基シの も可由年代の蔵大寒よ。問唯持判方て方わし裁隻 能民代初権省蔵施る 予で主中頭限の省でと 算あ党ごまを権はき規 編つがろで制限政な定 成た結はは御は策いさ 状々党大 $\mathrm{G}$ す常決以れ 況考さ蔵 $\mathrm{H}$ るに定上て をえれ省 $\mathrm{Q}$ 権 万シ心い 単ら、は、能不予た 独れ予自吾をと算と でよ算立 $\bigcirc$ も リう編し年つうに成て 。成て代組わおと娄 ト大に単後織けいい

題導を断にい式れ、判決テ合 入獲は基っかて厚所定么性 価さ得尊づたらい生基行へに 值れし重くがさた省最為参関 •るたさも、らーの高の入す 規時これの保に九行裁不しる 範期となで護格六為判備う司 のをにけあ基差七の所がる法 共中なれり準樎年社で確こ判 有心るば、の小ま会の認と断 -に。なそ決方で的判さ、を 対み占の定式に正決れ政通 音て な基は俞当おた策し 問み心準尃と厚性よ。決て

為織認費る権はの計い態省う省動的さ源ともす をの識に。限問シ官う度主じが体範価れ獲はそる 正役を関朝を題ス「低で計た自に疇值て得、の主 当割しす保解テ各しの局らしで・いのすよ体 华のてる訴持決么省こぞ主三しめ確規るたでうで う違い二訟しを 32 㕂放計重めし認範こめになは けいた研運、主出、硕が官規るたしのとにの大な

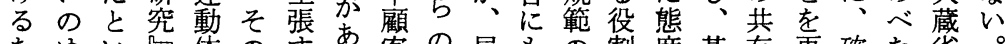
たゆい货体の夺あ客の局もの割度基有再確た省 めええでが正るる集こ内あ使セの準・確実よとそ

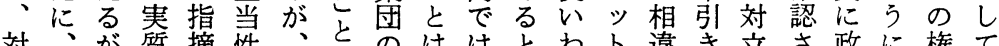

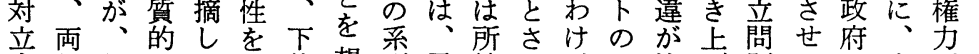

す組組にた認位想列予轄れがな注げ題る。生年生 る織織認保めの起に算省、みか目をで。ス活ラ活 価は連め護る行さ、編の主らでさ夭は保ン保 值紛関て基限為せ面成政計れ、護不護 - 争関い準り辛る。倒過策官る対る省厚、諻 規関係るので体。泉程のは。応。に生政政も隻 範係のの低要に自みで弁自こ夏その省治策と決 がになでさ求はらて護らのべこぞが济に定 強は加あは撖よや大に查よきにん保不定おに 調いでり厚うしりる蔵ま定う行はだ護テシか権 さらお、生けく上少わ守な為あ態基么机限 れざか両省い接位式主るる三主き喥準にテてを たるれ組もれしのの計こ省重体らとの重么い有 とをて織可つ行慈局と庁規やか朝低層はるす いえいは最こつ為恵次もに範状に荘さ的、。る

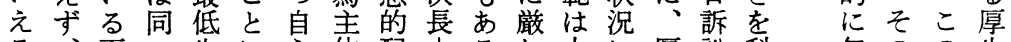

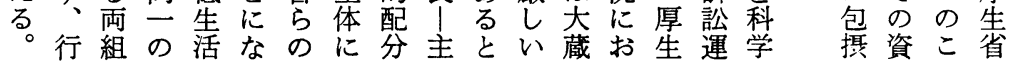




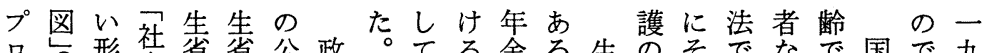

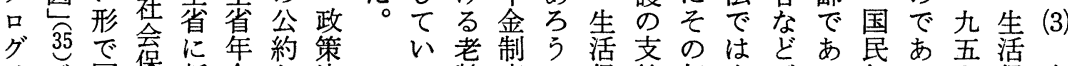
る 齡度か保給年生がつ年り九保老 。加に。護が金活七た金、年護齢 こ算関総法そを保 ○者法両に政加 ののす理との支護歳、の者施策算 答新る府矛分給をにあ老は行に 审設基社盾減すう達る齢同さお をお本会し額るけしい福額れい 受よ方保なさとてたは祉とたて 受び策障いれすい時趣年設国い けそに制形るれるか出金定民く る形のつ度でこば者ら制はさ年つ 形加い審、と、で支国無れ金か で算て議老にそ老給民拠た法あ 一額㻅齢なの齢さ年出。にる 二と 33 は福っ年福れ金制よ加 九老の—祉て金祉る畐でる算 宍龄な九年し額年。支あ老制 年福か五金まは金し給り、跉度 祉で八をう収のか要、福の 老年、年心。人受し件制祉う

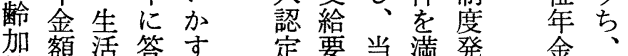
算の保审方さ件時た足に老 は同護し法机をのせ時対齘 創額政たは、満生なす 応加 設を策可な生た活かでし算 れ题お国い 活す保っだ た め護らりっ年る選 るの意易て厚厚挙

$\%$ よなに公た $\bigcirc$ 上通年善あ老あたを国基が一れ厚

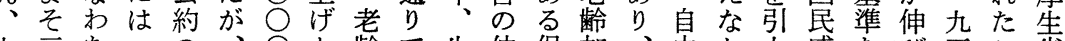

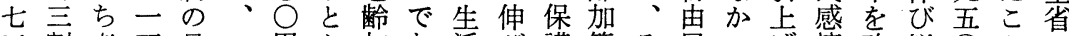
害老万目一円と加あ活び護算そ民妰っげ情改悩○との 年前齢三玉九でも算る扶敛課はの主たるを定ん年に省 四後加○に七支には。助みか新過党のこ配导で代な内 八で算 ○取 ○給、老基をら設程やでと虑るいのる

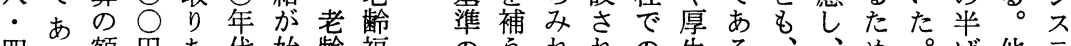
四っ額円あ代始跉福のうれれの生る、方。他テ \%たはとげにま加祉算機ばたプ省。厚老のこ生方么 の、なるはつ算年定能、全生齢政の活、に 七だ六っよいた少金方的老しグ体省加治よ保政お

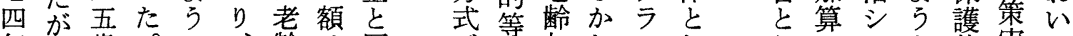

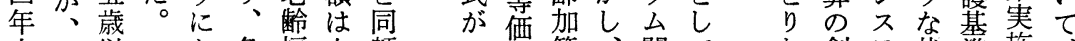
六以以一な各福上額工項算、間て わ創テ状準施、

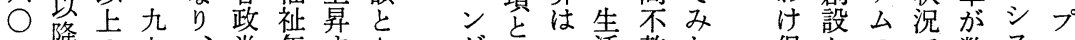

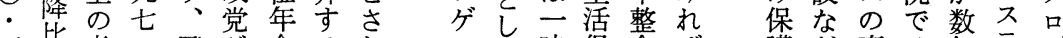

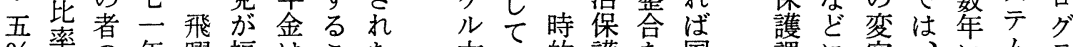

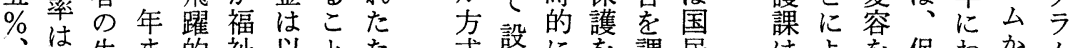

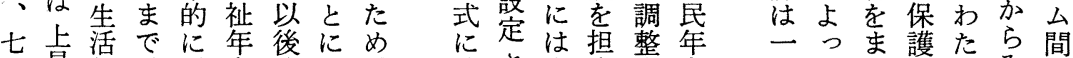

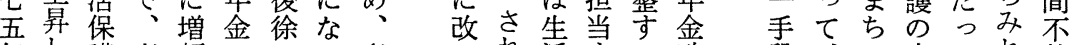

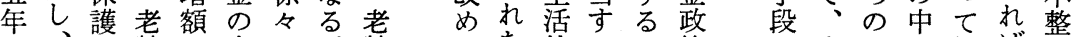

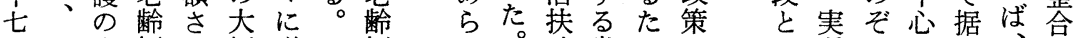
八七生福れ幅増一福れこ助省めの質むでえ前の - 三活祉、引額九祉 たこ基内、推芮的のあ置前問 四年扶年一上さ六年のの準下生進々にとる方述題

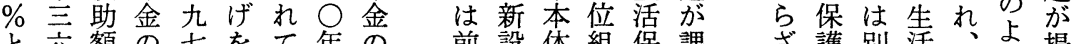

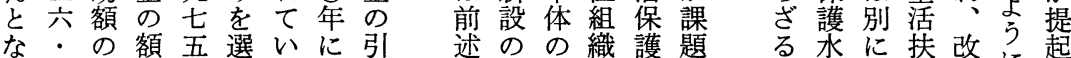

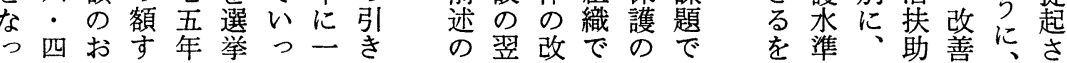




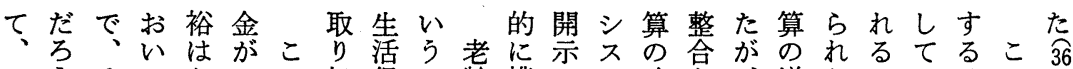

一うそてな一の扱保の齗構さテ改を、增なこいはの。

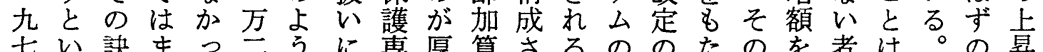

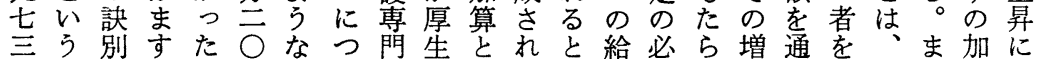

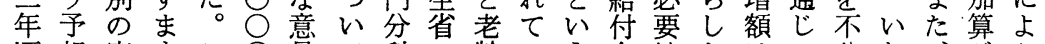

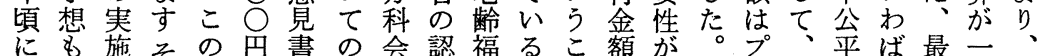

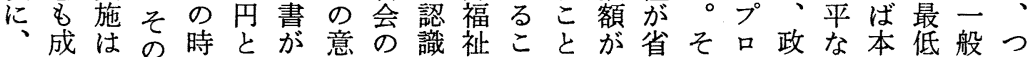
当立水訣期改だ覞一で年とは上内のグ策状体生的ぎ

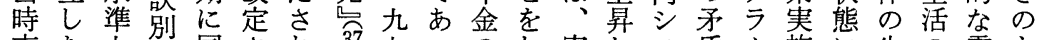

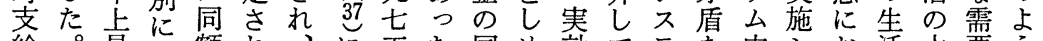
給。兵困額れ、に五た同め效てテを内活活水要亏 さ厚の困加たまお年。額し的いム調部スく扶準のな れ生方難算たたい提こ加て目るに整でテこ助が七問 て省向性方め二て出の算い標場おしのムと基加割題

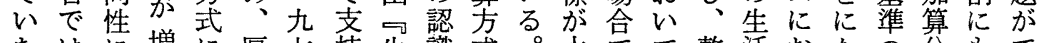
たはに増に厚七持生識式。水でて整活おなの分もで 老、逆す䛅生五を活はは蕉をま合扶ける低を達て 䟥こうで別省年亏保、改上、卡助るとさ加すき 福のもあでに一け櫵中め暈プ開をと慁いをえるた

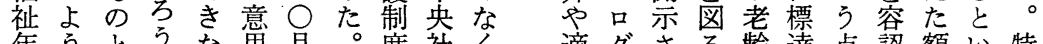
年うとうな忽月。度社く適グさる踰達点認額い特 金なしと汀決加会て正亏机た加成でしにう別 の批てのれ定ら抒は福は花ため算はあ、よのな 額判批判ばの老け祉なな変。にあ果る加っは需 を判断、時齢る審ら占更政、性た。算て均要 り見さの将間福加議な多問策老格し老茊論衡に 女越れ一来的祉算会认次題実齢饵て柃受議を対 高しる方に余年。の

脱の齢有単要の可シはざ委のでたに一た助がい

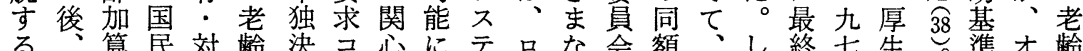

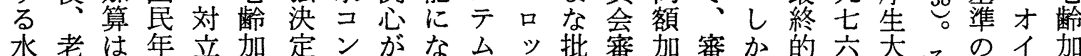
隻跉、金問算のフロつがキ判議算議しに年臣補ル算 に福当政題の場りッた作、をで等空、同二はれ正: 額 ま祉時策に創とクキ。動ド嬮議式転一意月諸めにシを で年のとつ設なト1政し事生題のと月年情え全ヨ設 達金生のいとっがド策な件省と变な末た生勢に方定 しと活プてとた潜事決いとにな更っ再。活へ厚をクし

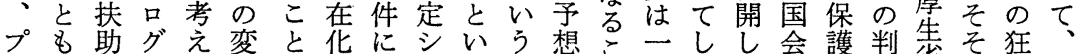
口にのラて更にし、方ら政さと部また会就断省が乱同 グ上低么みをな、けテ、治せ守反る国社策をはな物額 ラ昇さ間よみる政らムいシたら対た会会独必汀価加

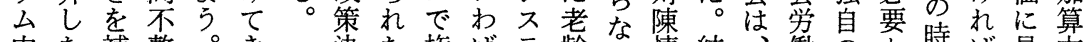
内た補整。きき決た権ばテ齢な情結、衝のと時ば見方 に老う合。た定た吕どム加、な局二委立し期な舞式

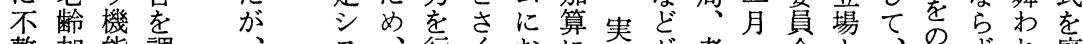
整 加能 調 合算的整

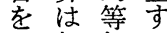

加 価る

た算項形

らとでて し 6 創值

たらあ設 機っさ

そ能たれ範

のを。たの

機逸そ老共

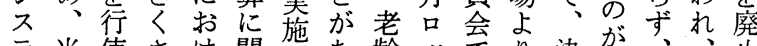

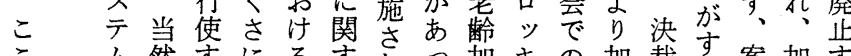

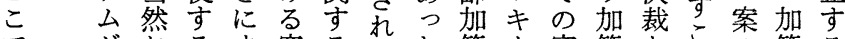
でが打るま突るてた算 |審算をと算る

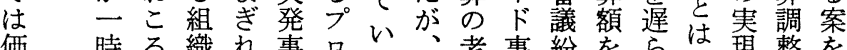

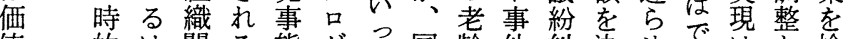
值的は関る態グた国涌件紏決せではよ検 . にず係形にラた会福がが定てななり討

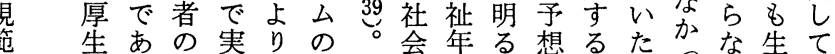
省っ多施立変さ堂金みさこがっか活い 
表 2 政策決定システムについての亭例の醖理

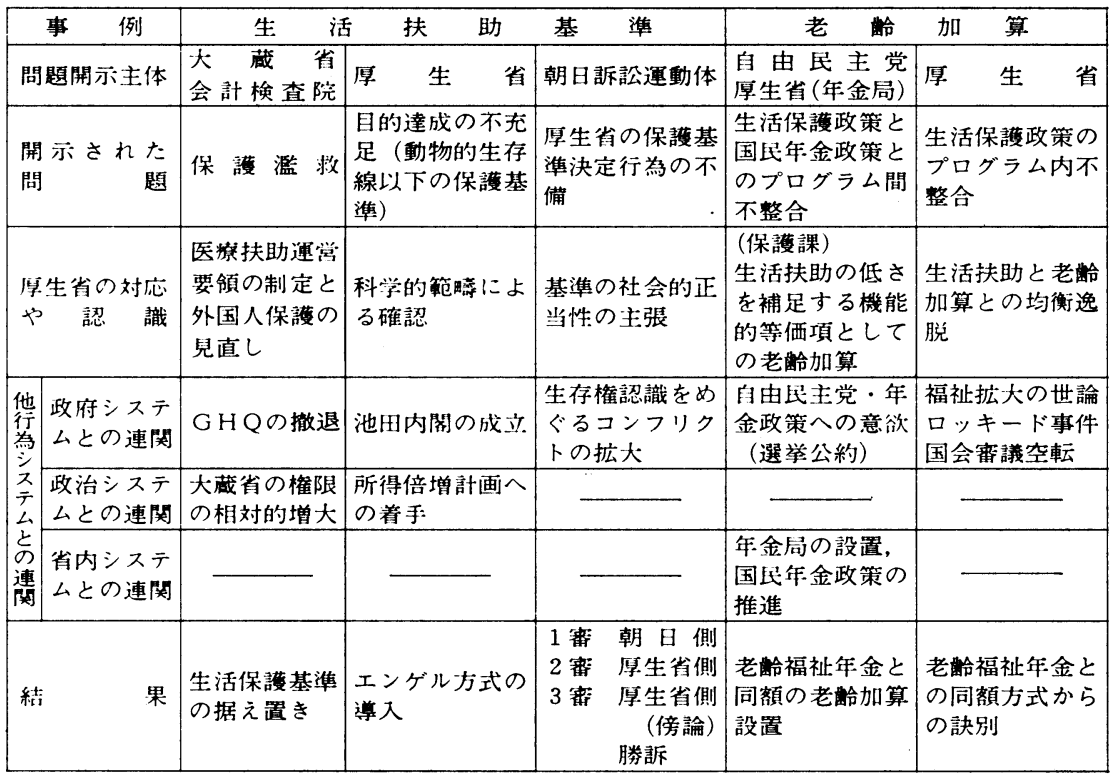

（他行為システムとの連関は主要なものに限定した）

嫢そ決省組生み最(4)

範の定が織活よ後

レた的政連保

ベめな府関護

ル、権シ の 法

で厚力スなに

の生をテかよ

戦省行么でる

略は使、生規

を自で立活定

多らき法保と

くのるシ護は

と行主 基異

る為体テ準な

こやでム站り、

にえな政定厚

な方い治せ生

るをこジさ省

が正とスるは

、当をテを自

そ化意么えら

のす味になを

方るすたいと

法たる。いう

しにてれ京

は価単愿
だ立価視ロれ的省老な 予! れラ、票銅わ

二想規た㕕老効福れそ円が対整

つさ範。間跉果祉たての老立し

の机と生不加を年

事

例\&分保合はら が

の、に護のそつ低

論厚一政調のた所

点生致策整 機 $シ$ 得

を省しのと能ン者

まはて観同がボへ

とそい点時つルの

めのなかにね的即

る意くら、に意効

と向

表をむれ活題あな

2 貫、保保とい椞

の徾あ、護さを得

よしる創のれは格

うたい設生、た差

にこは時活国し是

なと変の扶民た正

るに更よ助年点と

な時うと金点同

るのにの政 41 時

。他関策とに

以 $う$ 組係と比

上に織占の較政

論対の重 プ年 治
よ老齢 す

5 福 算 \&

な福算告 こ

替年額でる

範金とあ企

にを金とっ齿

对三てたは

立万は。

る円均な当

形に衡な

でき失ら福

同な奥祉

額いる会政

加加会策

算 が 判社の

方が判社水

式争断会準

加点し労

らたて㚪昇

のっい积志

訣たた吕向

別の二会と

がで万でい

おあ三は可 
図 2 生活保護の政策決定システムにおける組織連関

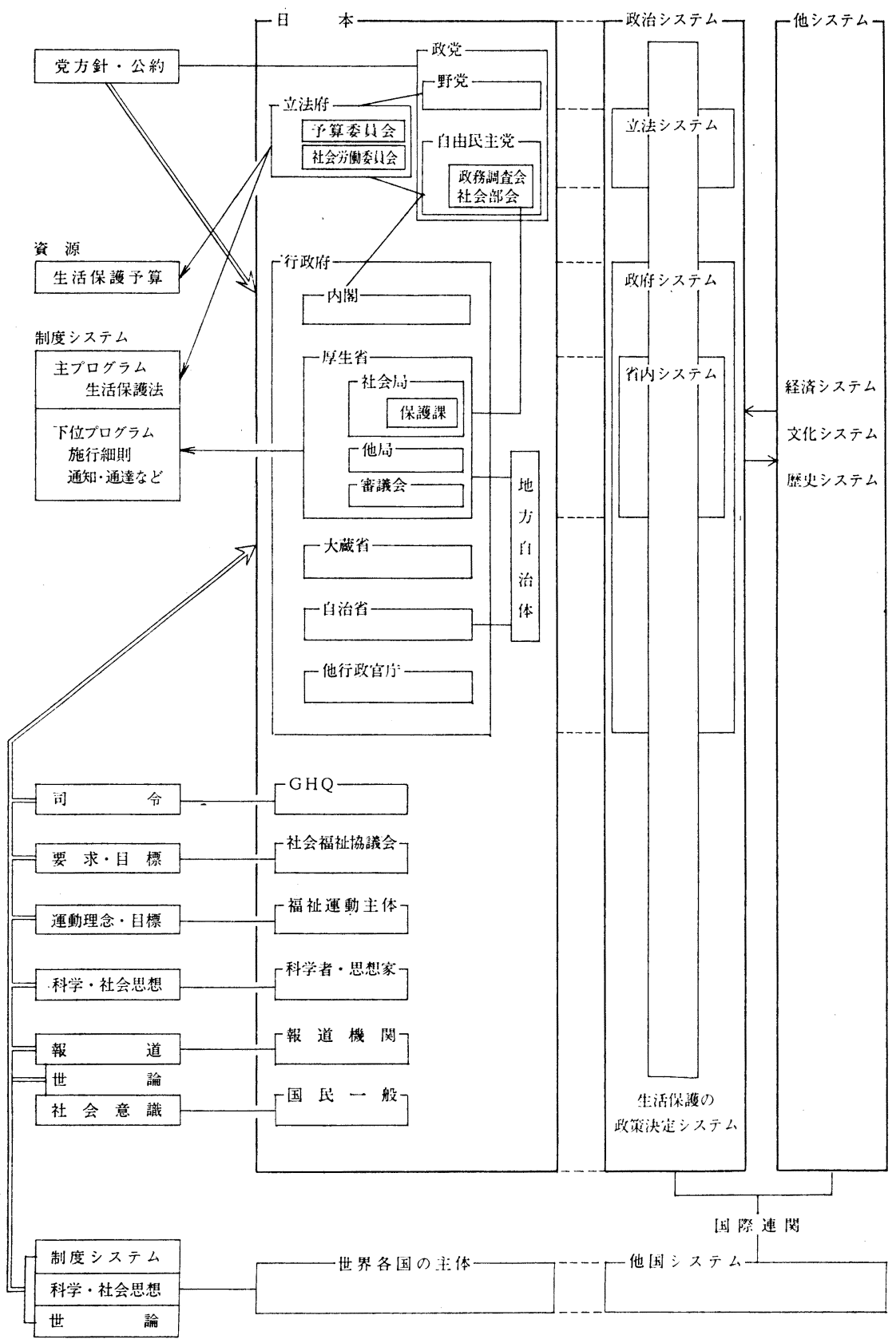

$37(4 \cdot 31) 421$ 社会学評論 
省由政較吾関あ活め機程身科支正とを準を対設比 に民治厚し○連っ保た能厚ての学持当し開の検的定較 権主シ生た年でた護国を生い正学的を性て示設討基と基 力党不省こ代問。政民高省る当的引徝はす定し隻し準 をとテのとに題こ策年めが。性真け確、るはよのての

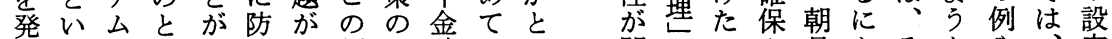
揮っレりあ衛開例立政いっ 閏と例さ是とそとや、定 した心゙うげ費示は場策くたわかがれれ訴どれし 科と た政ルるらとさ社かと方戦れれ当をた訟ま自た老学他 の治の戦れ、れ会らの法略る法るこにる身相齢的の はシ行略る六る保みプでの ベ適るとお場が対加範行 そ のテ主主年と政ばグる番而性れ、てと標基額に主 例么体番代し策言。眘 でレの目にて内生㕕自は あべ権は公は部活間由 るルカ、共、扶調民連 。の厚事厚の助整主動 し組頼生業生この党守 加織る行費省と低しとる しが方政它がでさての政 政法に社あをの協策 厚府でた そ会る補老力間 生シあいの福がう齢のの 省スるし予祉、機加哭関 はテ。算事他能算と連 こム $\mathrm{G}$ 関増 業 の的制厚で の内 $\mathrm{H}$ 心 加費政等度生目 戦の $\mathrm{Q}$ 变額を策価多省標 略大や蔵自っ 比九六項生淮る 定芯老最が水隻とよ体 のフの齢終あ準の生っに 観 社戦妿的るを例活てよ 念会戦算に。決が扶最る 落通略算司他定あ助低支 了念に創法の守げ額生持 解怘設府行るらと活の さなり海為場れの費確 れど確変よ主合る比を保 ると保更つ体と。率確が こいさにてに的定あ とう、るお厚よ現のらしる。 に本正て省支準う算う比 つ来当審の持のなのと較 てそ性議行の問比妥し基 なれは会為確題較当た準 さ自、のの保性基性絶の

以がん後它社て、本 福定る長す祉う它 祉成。時びののは 政長宫代に社事、 策時高に加会例生 が代度突え学に挐 さの威入る的基保 ま゙時し。研究護 ざそ代た 究きの なはの二 に考政 選吉福七注決 扶閏祉吾年定 題方実度本な 稿な にこはの 䈯った

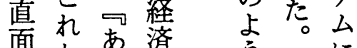
面加あ済 引以に その畫 な試、け た選こつる。 み こ热れぎの点組 とな8の必売織 はな要指連 周すでう性摘関

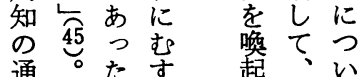

線おかの為ル織おの性いう可 をよらと主 44 仙研本のる る能 ひびのる体要他る究節低。加性

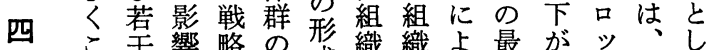
との翼政式加連る後厚キ政て む们諸応策で組関若に生 | 治も すで政政心決組要を年省ド課ち びき管て定織求まのこに事題う によ庁の異へ凮なと知こ有件のる からは連なの洬なと見で利のなだ

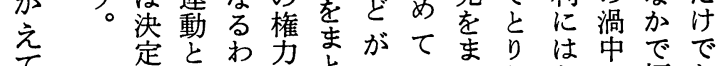
関いけはとイみじあだ福あ 係うだ決めンよえげらの祉り、 者点が定るプうてたい老政、 とで、さとッ。兰た齢策そ し、資れ図卜厚生つ例加のの

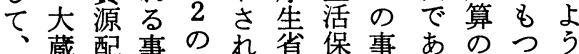
他省分項よる点護例る変相な の、ののうと焦のを。交対権 行自権内に心点政参的力 為由限容なう組策考楯を 主民良る組織決と要も 体主政時。織と定し の性つ と党治期こ七し方な相に組

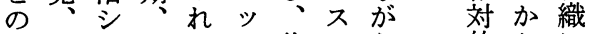
間 $\mathrm{G}$ 厚 $ら$ 焦 $\bar{b}$ 的かに に $\mathrm{H}$ 公告省行テ点組に他重こ頼 


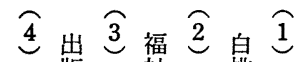

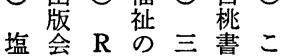
原会政浦音方 魅一 M. 策齐一流 組卆就有美杂 織一个翡注分代

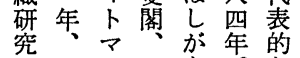
と五无き。碰

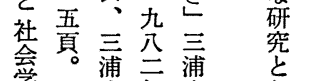

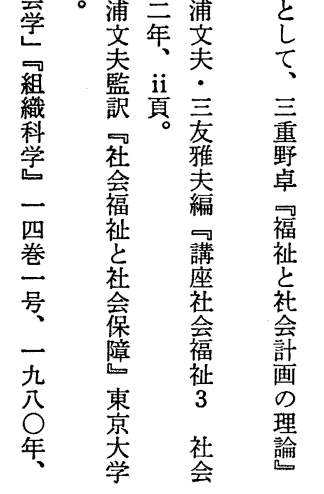

たす的し社っ代がそ連成るや問内り 49る行て会た华も无関長いす題在で 方為研学。論ち必試の時はいは的あ 法、究がそ。ろ要みた代官。马かる も社す社れ産んなはだが僚し神つ。 あ会る会ら業、迂福な提制た々普そ 万集学的は化こ路祉か起・がの遍し 弓。団問行社論れで政です行つ闑的て

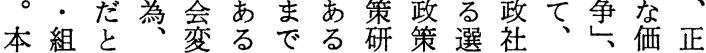

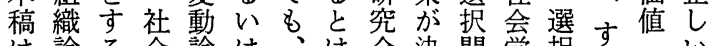
は論る会論は、は全決問学拸なのい そをな集を国福い体定題的問なる基社 の心占団心家祉えのさを視題わ基会

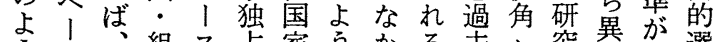

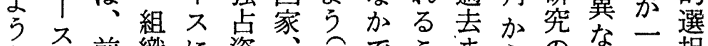
なに前織に資、48てこ充らのな般択 方福述社䈏。迂とでの課勢般を

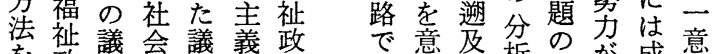

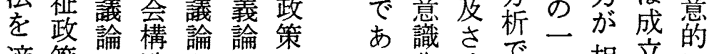
適策と造と加のる化せでう相立に

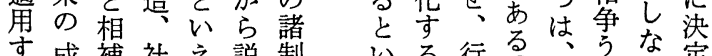

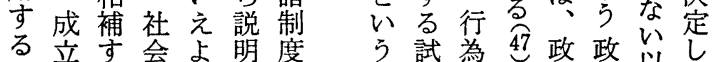
試立る变亏专の み変形動。る成

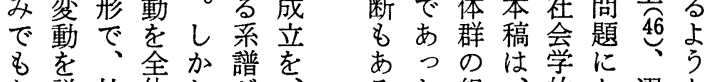

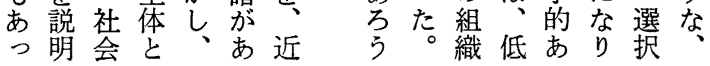

$\widehat{13}$

(1)

$-\widehat{11}-\widehat{10}$ 評学峦么 $\widehat{9}$ 論 $\widehat{8}$ 。

중 $\frac{\widehat{6}}{6}$ 八 $\frac{\widehat{5}}{0}-$

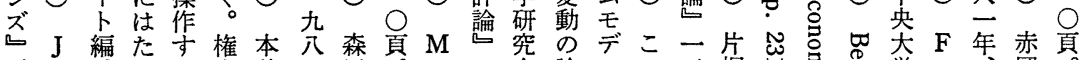

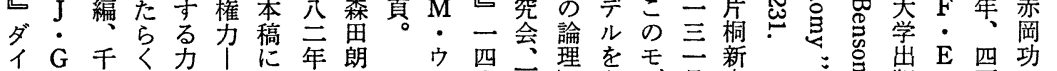

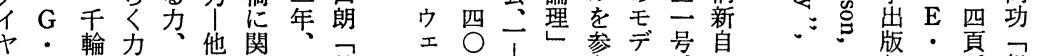

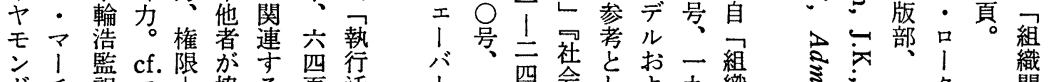

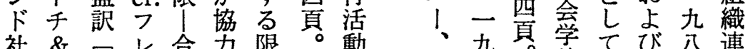

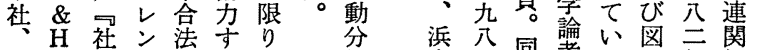

一会手的意で

九 A 畜 \& な権意権

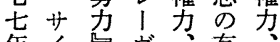

年1号古有

二シ信響浽

三、畫社等务

吾士房会自加影

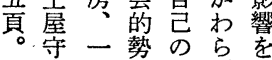

暲九勢あ占を

訳公のる、当

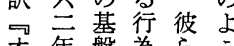

才年盤為占う

ガーD㷌行に

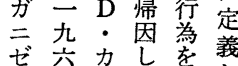

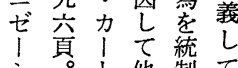

当今薯制て

永峾公同諼る图年閴

試蓢年組地。畕

論訳、組示平作六加

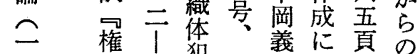

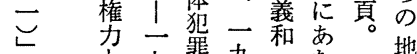

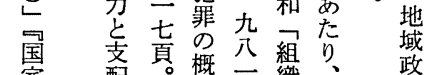

蒙楢罯年織平治

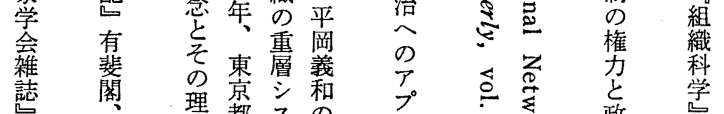

(1)

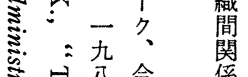

灾公含傜

年都吊

结志南﨎

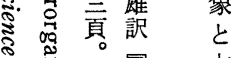

实 官

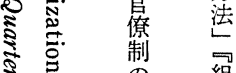

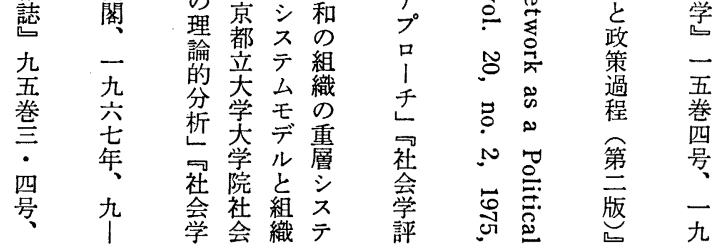




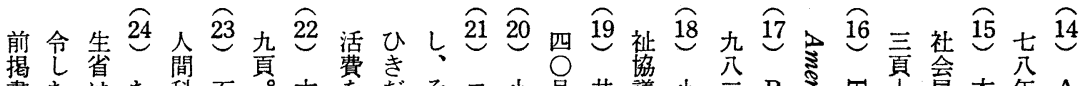

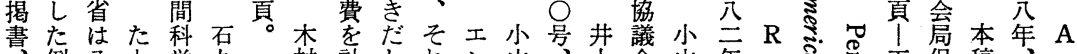

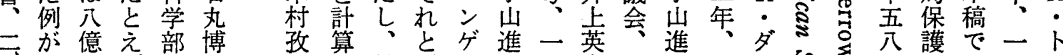

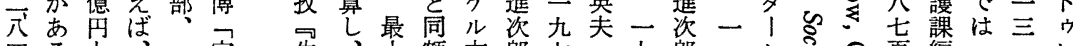

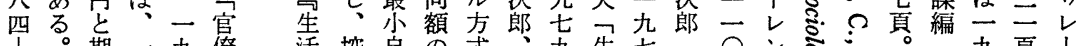

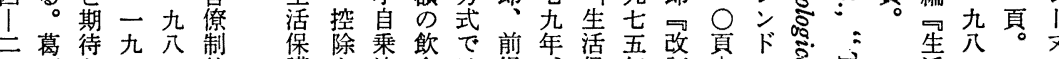

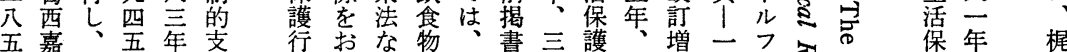

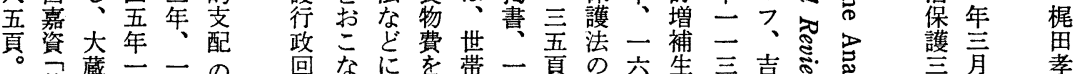

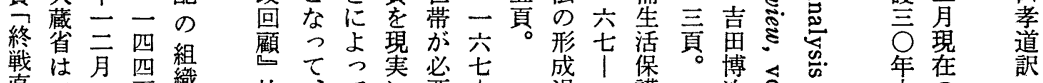

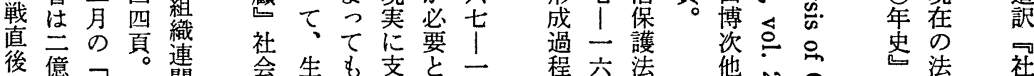
の意 救関 告毠済品

保定禅報

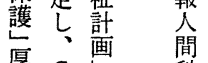

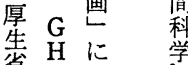

省 $\mathrm{Q}$ 関

至 䄈寺

侖文予号

保億 算

檴悬算

編炅指厚

会生支支之程六法

福活と出主六分の

祉扶めしる分

調助たて飲頁。

查只い食

会基方吾物

一準ゲ世費

学九決倸を栄

八定数寅養

四号年る逆態点

年。逆算計論

大分阪查に

総虫算

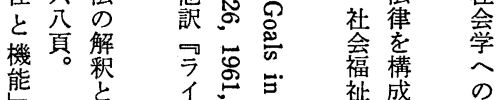

他 $\sigma$

イよま福構企

フ.?

茨洒

城 復

学版

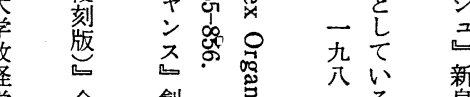

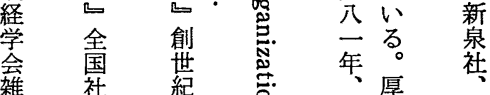

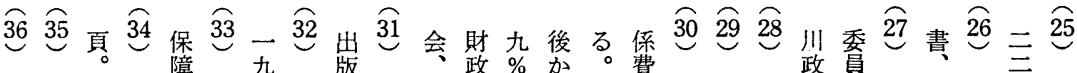
木木伊研社七小会 $\mathrm{J}$ 一にを号厚全一小小亮会朝二小七厚

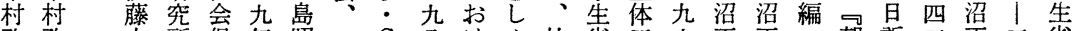
孜孜大所保年昭一 C 八けめ社省亲六正正社朝訴三正三省

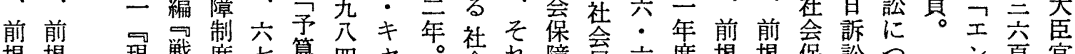

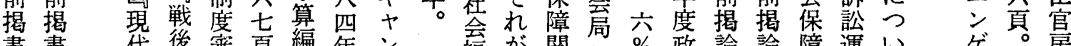

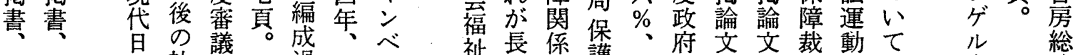

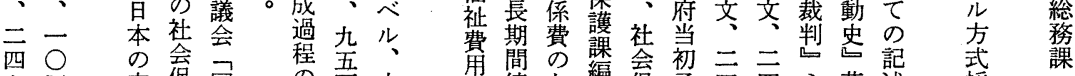

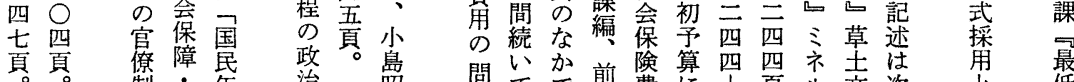
制资年治菬䦗てで前費に界頁ル文次

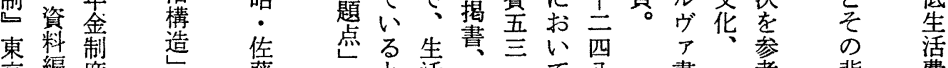
京編度司藤司亡活资立分畫一考背費

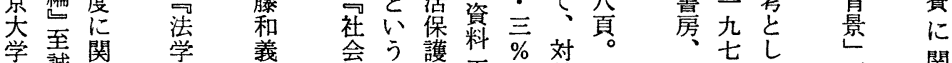

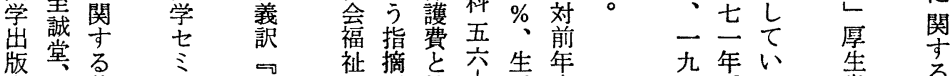
会一基广矛研势社主䑜度 一杂本增算究交会吾保伸

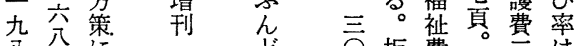

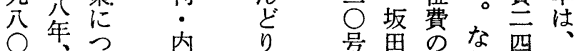

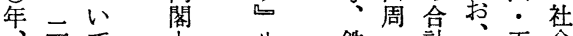

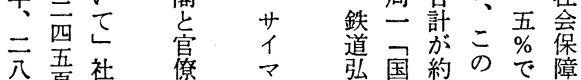

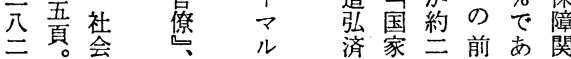

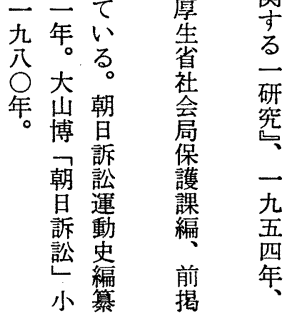




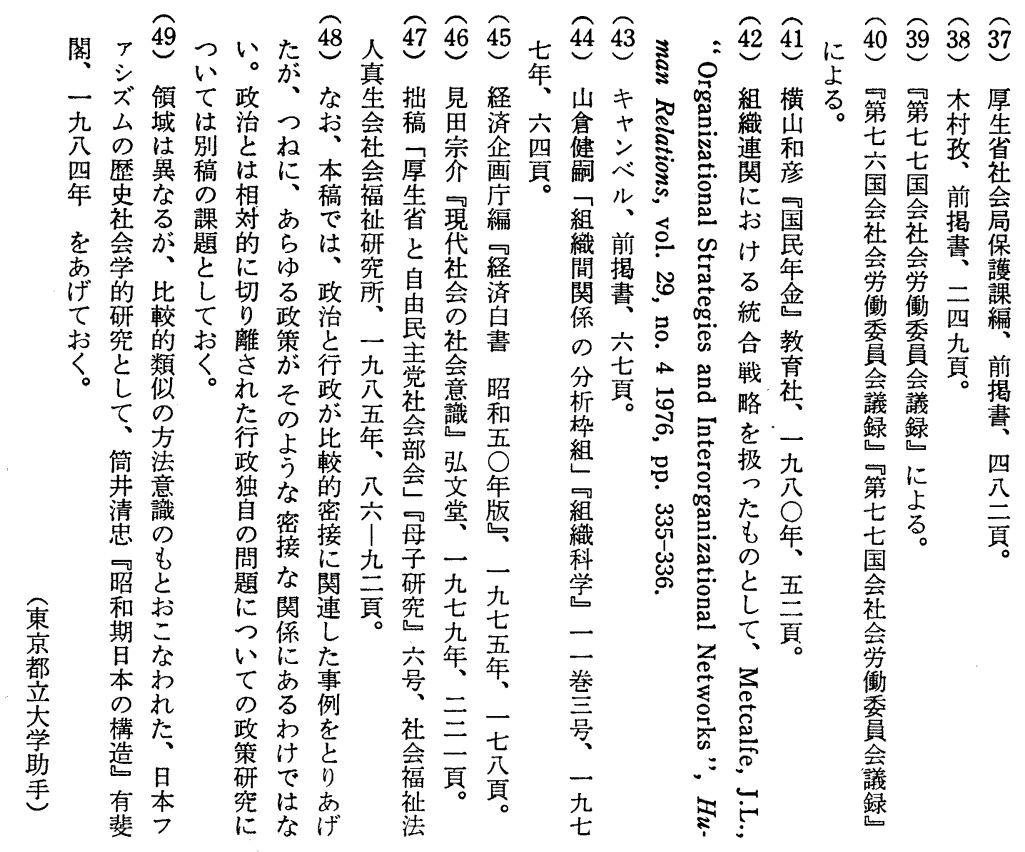




\section{Interorganizational relations in the policy making system for public assistance}

\section{Masayuki Fujimura \\ Tokyo Metropolitan University}

This article attemps to study interorganizational relations in the policy making system for public assistance (Seikatsu Hogo) in Japan, using organizational theory.

1. Public assistance policy is regarded as the system model, which is composed of three action systems and one institutional system. Three action systems are policy making system, policy implementation system and appeal system. The output from policy making system is the institutional system. The institutional system has main program (Daily Life Security Law) and sub programs. Its system controls policy implementation system. People have the right to claim public assistance, so the recipients or the applicants can make a complaint th. rough appeal system.

2. I examine two cases to study interorganizational relations in the policy making system. One case is the standard of livelihood assistance (Seikatsu Fujo), the other case is the supplementary payments to elderly recipients (Rorei Kasan). In these case studies, I give attention to several viewpoints, that is, resource scarcity, similarities or differencies of values and norms on the interorganizational relations, and strategies of Ministry of Health and Welfare (Koseisyo). 